\title{
Editorial
}

\section{Impact of Large Wood on River Ecosystems}

\author{
Isabella Schalko*(i) and Volker Weitbrecht $\mathbb{( \mathbb { B }}$
}

ETH Zurich, Laboratory of Hydraulics, Hydrology and Glaciology (VAW), 8093 Zurich, Switzerland; weitbrecht@vaw.baug.ethz.ch

* Correspondence: schalko@vaw.baug.ethz.ch

Citation: Schalko, I.; Weitbrecht, V. Impact of Large Wood on River Ecosystems. Water 2022, 14, 784 . https://doi.org/10.3390/w14050784

Received: 3 February 2022

Accepted: 25 February 2022

Published: 2 March 2022

Publisher's Note: MDPI stays neutral with regard to jurisdictional claims in published maps and institutional affiliations.

Copyright: (C) 2022 by the authors. Licensee MDPI, Basel, Switzerland. This article is an open access article distributed under the terms and conditions of the Creative Commons Attribution (CC BY) license (https:// creativecommons.org/licenses/by/ $4.0 /)$.
Large wood (LW) can be defined as logs with a length of $\geq 1 \mathrm{~m}$ and a diameter of $\geq 0.1 \mathrm{~m} \mathrm{[1-3]}$, and is also commonly referred to as instream wood or driftwood. Transported LW in rivers may accumulate at shallow water areas or at natural and artificial obstructions, thereby forming LW accumulations or logjams [4]. A key log, characterized as a large piece of wood, may initiate and stabilize the formation of a logjam $[5,6]$. The logjam formation further depends on the existing flow conditions and the volume of transported LW [7]. In general, logjams can have different sizes and may partially or fully span the channel width. As logjams block (part of) the channel, they act as a porous obstruction, leading to an increase in water depth and decrease in flow velocity upstream of the logjam [8-10]. In addition, a region with reduced velocity (wake) is established downstream of the logjam, promoting the storage of fine sediments and nutrients [11-13]. As logjams create flow variability, they provide habitat for many different species. The number of river restoration projects including LW has significantly increased within the past decade [14]. To further improve restoration efforts, it is important to understand the LW transport dynamics and how LW affects and interacts with flow, sediment, and fauna. Recent floods in mountain regions demonstrated an increase in sediment and wood-laden flows, which affects the design of hydraulic structures $[15,16]$. The majority of LW retention structures consist of vertical poles to the horizontal that span the entire channel width [17]. This design significantly affects the flow and bedload transport conditions. Specifically, the ecologically required bedload continuity during low flows may be impaired. Therefore, innovative monitoring and design concepts are required that sustainably manage bedload and LW transport.

This Special Issue highlights topics related to the impact of LW on river ecosystems including fundamental research and practical applications. The five contributions focus on benefits as well as hazards related to LW in rivers, and include innovative engineering solutions and novel methodological approaches.

Polednikova and Galia [18] performed a systematic literature review on ecosystem services of LW in rivers and derived knowledge gaps. Based on the 'Preferred Reporting Items for Systematic Reviews and Meta-Analysis' (PRISMA) protocol and defined exclusion criteria, 137 papers were found on ecosystem services of LW in rivers and were used for subsequent analyses. The majority of articles focused on habitat creation and increasing channel heterogeneity, and were affiliated with researchers from one country. The authors point out the need for more international collaboration to increase knowledge transfer, which may result in improved LW management practices.

Neuhaus and Mende [19] provide practical insights in the planning process of engineered LW structures. In order to design engineered LW structures that are ecologically effective, the following aspects should be considered in the planning and execution phase: placement, heterogeneity, trapping effect, size, and naturalness. Three examples of river restoration projects in Switzerland demonstrate the various dimensions and effects of engineered LW structures. The authors conclude that the balance of the interests between risk management and ecological objectives remains a key subject in every restoration project.

Wyss et al. [20] conducted a field study at the River Glatt in Zurich (Switzerland) to analyze the LW accumulation process of single logs at a circular bridge pier. Based on 
the observations, the LW accumulation process can be described by an impact, rotation, and separation phase. An analytical criterion was derived by combining two simplified equilibria of acting forces and moments, which explained the behavior of $82 \%$ of the logs. In general, the field observations confirmed previous results on the LW accumulation probability in the laboratory, which supports the applicability of laboratory studies to investigate LW-structure interactions.

Schalko et al. [21] present flume experiments to study the effect of LW accumulations at an inclined bar screen with a bottom clearance on backwater rise and bedload transport. The main focus was put on testing different $L W$ characteristics. The results demonstrated that a few logs are sufficient to reduce the bedload transport capacity to below $75 \%$ compared to the condition without LW. Fine material and smaller wood sizes further reduced bedload transport and increased backwater rise. In contrast, LW density and LW shape had a negligible effect. The test focusing on a sequenced flood highlighted the need for maintenance measures to avoid self-flushing of the bed material.

Furukawa et al. [22] used flume experiments to develop a novel LW trap consisting of horizontal rods aligned with the flow. The goal was to separate LW from water and sediment, as LW deposits on the horizontal rods. During the flume experiments, a given LW volume was added to the flow and the resulting trapping rates were measured. Special focus was put on the effect of the relative LW length, defined as the ratio of LW length to the horizontal rod spacing, on the trapping rate. The results demonstrated that larger relative LW lengths increased the trapping rate, whereas no LW was trapped if the relative LW length was smaller than 1.5 .

Author Contributions: Conceptualization, I.S.; writing—original draft preparation, I.S.; writingreview and editing, I.S. and V.W. All authors have read and agreed to the published version of the manuscript.

Funding: This research received no external funding.

Acknowledgments: We would like to thank all authors for contributing to this Special Issue and the Assistant Editor at MDPI for the great support.

Conflicts of Interest: The authors declare no conflict of interest.

\section{References}

1. Keller, E.A.; Swanson, F.J. Effects of large organic material on channel form and fluvial processes. Earth Surf. Process. 1979, 4, 361-380. [CrossRef]

2. Nakamura, F.; Swanson, F.J. Effects of coarse woody debris on morphology and sediment storage of a mountain stream system in western Oregon. Earth Surf. Process. Landf. 1993, 18, 43-61. [CrossRef]

3. Piégay, H.; Gurnell, A. Large woody debris and river geomorphological pattern: Examples from SE France and S. England. Geomorphology 1997, 19, 99-116. [CrossRef]

4. Wohl, E.; Kramer, N.; Ruiz-Villanueva, V.; Scott, D.N.; Comiti, F.; Gurnell, A.M.; Piegay, H.; Lininger, K.B.; Jaeger, K.L.; Walters, D.M.; et al. The Natural Wood Regime in Rivers. BioScience 2019, 69, 259-273. [CrossRef]

5. Abbe, T.B.; Montgomery, D.R. Large Woody Debris Jams, Channel Hydraulics and Habitat Formation in Large Rivers. Regul. Rivers Res. Manag. 1996, 12, 201-221. [CrossRef]

6. Davidson, S.; MacKenzie, L.; Eaton, B. Large wood transport and jam formation in a series of flume experiments. Water Resour. Res. 2015, 51, 10065-10077. [CrossRef]

7. Schalko, I.; Lageder, C.; Schmocker, L.; Weitbrecht, V.; Boes, R.M. Laboratory flume experiments on the formation of spanwise large wood accumulations: I. Effect on backwater rise. Water Resour. Res. 2019, 55, 4854-4870. [CrossRef]

8. Schalko, I.; Schmocker, L.; Weitbrecht, V.; Boes, R.M. Backwater Rise due to Large Wood Accumulations. J. Hydraul. Eng. 2018, 144, 04018056. [CrossRef]

9. Follett, E.; Schalko, I.; Nepf, H. Momentum and Energy Predict the Backwater Rise Generated by a Large Wood Jam. Geophys. Res. Lett. 2020, 47, e2020GL089346. [CrossRef]

10. Follett, E.; Schalko, I.; Nepf, H. Logjams With a Lower Gap: Backwater Rise and Flow Distribution Beneath and Through Logjam Predicted by Two-Box Momentum Balance. Geophys. Res. Lett. 2021, 48, e2021GL094279. [CrossRef]

11. Skalak, K.; Pizzuto, J. The distribution and residence time of suspended sediment stored within the channel margins of a gravel-bed bedrock river. Earth Surf. Process. Landf. 2010, 35, 435-446. [CrossRef] 
12. Faustini, J.M.; Jones, J.A. Influence of large woody debris on channel morphology and dynamics in steep, boulder-rich mountain streams, western Cascades, Oregon. Geomorphology 2003, 51, 187-205. [CrossRef]

13. Schalko, I.; Wohl, E.; Nepf, H.M. Flow and wake characteristics associated with large wood to inform river restoration. Sci. Rep. 2021, 11, 8644. [CrossRef] [PubMed]

14. Roni, P.; Beechie, T.; Pess, G.; Hanson, K. Wood placement in river restoration: Fact, fiction, and future direction. Can. J. Fish Aquat. Sci. 2015, 72, 466-478. [CrossRef]

15. Ruiz-Villanueva, V.; Bodoque, J.M.; Díez-Herrero, A.; Bladé, E. Large wood transport as significant influence on flood risk in a mountain village. Nat. Hazards 2014, 74, 967-987. [CrossRef]

16. Comiti, F.; Lucía, A.; Rickenmann, D. Large wood recruitment and transport during large floods: A review. Geomorphology 2016, 269, 23-39. [CrossRef]

17. Schmocker, L.; Weitbrecht, V. Driftwood: Risk Analysis and Engineering Measures. J. Hydraul. Eng. 2013, 139, 683-695. [CrossRef]

18. Poledniková, Z.; Galia, T. Ecosystem Services of Large Wood: Mapping the Research Gap. Water 2021, 13, 2594. [CrossRef]

19. Neuhaus, V.; Mende, M. Engineered Large Wood Structures in Stream Restoration Projects in Switzerland: Practice-Based Experiences. Water 2021, 13, 2520. [CrossRef]

20. Wyss, A.; Schalko, I.; Weitbrecht, V. Field Study on Wood Accumulation at a Bridge Pier. Water 2021, 13, 2475. [CrossRef]

21. Schalko, I.; Ruiz-Villanueva, V.; Maager, F.; Weitbrecht, V. Wood Retention at Inclined Bar Screens: Effect of Wood Characteristics on Backwater Rise and Bedload Transport. Water 2021, 13, 2231. [CrossRef]

22. Furukawa, M.; Tsutsumi, D.; Muto, H.; Uchida, T.; Suzuki, T.; Horiguchi, T. Flume Experiments Evaluating the Efficacy of a Large Wood Trap Featuring Horizontal Rods. Water 2021, 13, 1837. [CrossRef] 